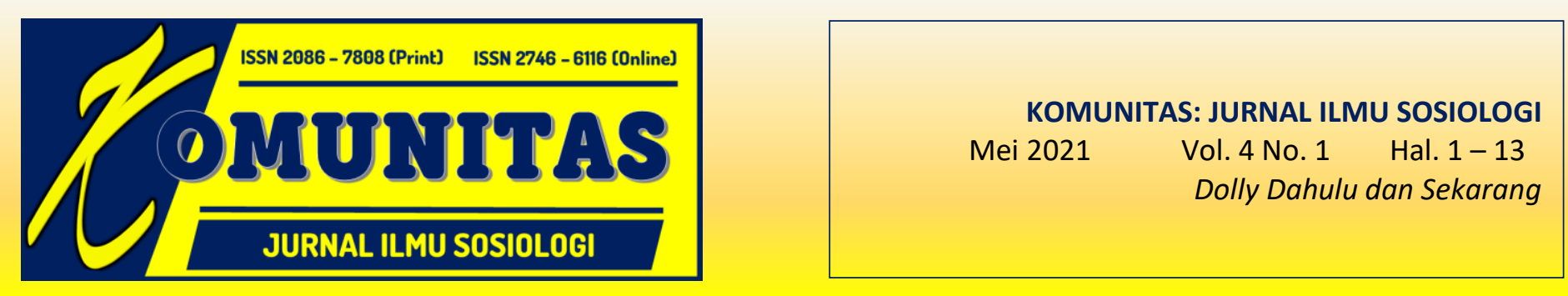

\title{
DOLLY DAHULU DAN SEKARANG
}

\author{
Ode Dedy Lion, Feky Manuputty, Prapti Murwani \\ Program Studi Sosiologi Fakultas Ilmu Sosial dan Ilmu Politik \\ Universitas Pattimura \\ dedyode19@gmail.com, manuputty1961@gmail.com, prapti.murwani2016@gmail.com
}

\begin{abstract}
Abstrak
Penelitian ini merupakan penelitian deskriptif kualitatif yang bertujuan untuk mengetahui bagaimana kehidupan dunia malam serta kesejahteraan sosial ekonomi di lokalisasi Dolly Kota Surabaya sebelum maupun sesudah ditutup. Penelitian ini dilaksanakan di Surabaya. Pengambilan data primer dilakukan melalui wawancara tatap muka maupun wawancara online karena situasi pandemi Covid-19 yang melarang adanya aktivitas diluar rumah. Hasil penelitian ini menunjukkan bahwa terjadi perubahan besar pasca ditutupnya lokalisasi Dolly di Surabaya, terutama dengan perubahan sosial ekonomi masyarakatnya dan perubahan pola interaksi terkait aktivitas seks komersil di lokalisasi Dolly. Kebijakan pemerintah yang di satu sisi menjadi keuntungan bagi kalangan tertentu namun di sisi lain menjadi kerugian untuk orang-orang yang menggantungkan hidupnya di lokalisasi dolly itu sendiri. Pelatihan kerja 3 hari dan kompensasi sebesar Lima Juta Rupiah dirasa hanya menjadi "uang hiburan sementara" bagi para eks pekerja seks komersil di wilayah eks lokalisasi Dolly. Oleh sebab itu perlu pengkajian lebih dalam dan solusi yang benar-benar mensejahterakan rakyat agar tidak terjadi kesenjangan sosial ekonomi pasca ditutupnya lokalisasi Dolly
\end{abstract}

Kata Kunci: Dolly, Lokalisasi, PSK, Sosial-Ekonomi.

This research is a qualitative descriptive study that aims to find out how the nightlife and socio-economic welfare of the Dolly localization in Surabaya City before and after it is closed. This research was conducted in Surabaya. Primary data collection was carried out through face-to-face interviews and online interviews because of the Covid-19 pandemic situation which prohibits activities outside the house. The results of this study indicate that there have been major changes after the closure of Dolly's brothel in Surabaya, especially with changes in the socio-economic community and changes in interaction patterns related to commercial sex activities in Dolly's brothels. Government policy which on the one hand is an advantage for certain groups but on the other hand is a loss for people who depend on the dolly brothel itself. The 3-day job training and compensation of 5 million Rupiah are considered to be only "temporary entertainment money" for former commercial sex workers in the former Dolly brothel area. Therefore it is necessary to have a deeper study and a solution that will truly prosper the people so that there is no socio-economic gap after the closing of Dolly's localization.

Keywords: Dolly, Localization, CSW, Socio-Economy 


\section{Pendahuluan.}

Berbagai macam pandangan orang terhadap kehidupan PSKyang sampai saat ini menjadi hal yang hangat untuk diperbicangkan suka atau tidak suka terhadap mereka yang berkecimpung dalam dunia malam tersebut. Akan tetapi bagaimanapun beragamnya pandangan, kegiatan seks sebagai komoditi tetap terus berlangsung.

Berbicara soal PSK sama saja dengan membahas hal yang sudah ada sejak awal mula peradaban manusia. Masalah lama tetapi tetap terasa masih baru untuk tetap dibahas. Sulit menentukan secara pasti kapan munculnya profesi itu. Namun, bisa dikatakan bahwa sejak adanya norma perkawinan, konon bersamaan dengan itu pula lahir yang disebut dengan PSK. Mengapa demikian? Sebab, PSK dianggap sebagai salah satu bentuk penyimpangan dari norma perkawinan di dalam masyarakat. Hubungan seksual yang dilakukan antara dua jenis kelamin yang berbeda dilakukan diluar tembok perkawinan dan berganti-ganti pasangan, baik dengan menerima imbalan uang atau material lainnya.

Dolly merupakan salah satu lokalisasi yang terletak di Surabaya, Jawa Timur yang terletak di Kelurahan Putat Jaya Kecamatan Sawahan. Pada pertengahan bulan Juni 2014 Walikota Surabaya, Tri Rismaharini mengambil kebijakan untuk menutup lokalisasi terbesar di Asia Tenggara tersebut. Jelas ada pro dan kontra dengan penutupan Gang Dolly, Misalnya saja dengan para pencari rezeki di Gang Dolly yang sangat menolak keputusan Walikota Surabaya untuk menutup lokalisasi tersebut. Bukan hanya PSK saja yang memperoleh hasil dari Gang Dolly tetapi ada berbagai macam profesi, Contohnya pencuci baju, PKL, salon, tukang parkir, becak dan lain-lain. Munculnya pengangguran baru yang setelah terjadi penutupan dan itu akan menimbulkan masalah baru di Kota Surabaya. Karena kehidupan di Dolly tidak terbatas pada aktivitas PSK saja. Ada perekonomian rakyat yang bertumpu pada berjalannya kehidupan lokalisasi yang berarti yang dapat membuat perekonomian rakyat semakin terbangun adalah aktivitas PSK di Dolly itu sendiri.

Berbicara tentang lokalisas Dolly dulu dan sekarang, tentunya tidak terlepas dari perubahan sosial yang terjadi di kota besar yang notabenenya menjadi pusat perubahan sosial dan teknologi pada zaman yang serba maju seperti sekarang seiring dengan lajunya pembangunan di kota besar itu sendiri. Perubahan sosial adalah perubahan yang mencakup sistem sosial dan terjadi dalam waktu yang berbeda, dalam waktu singkat dan juga lambat. Perubahan sosial mempunyai menjadi tiga konsep yaitu, studi mengenai perbedaan, studi 
harus dilakukan di waktu yang berbeda dan pengamatan pada sistem sosial yang sama. Pertama, studi mengenai perbedaan adalah di dalam perubahan sosial kita harus melihat perbedaan yang menjadi fokus. Kedua,studi harus dilakukan pada waktu yang berbeda, maksudnya adalah perubahan sosial itu terjadi dalam waktu yang berbeda. Ketiga, objek yang menjadi fokus studi tersebut harus pada objek yang sama. Setiap masyarakat dalam kehidupannya pasti mengalami perubahan-perubahan walaupun ruang lingkup perubahan tidak terlalu luas. Perubahan-perubahan yang terjadi di dalam masyarakat dapat mengenai nilai-nilai sosial, norma sosial, pola - pola perilaku organisasi, susunan lembaga kemasyarakatan, lapisan-lapisan dalam masyarakat, kekuasaan dan wewenang, intreaksi sosial dan sebagainya. Para sosiolog mengklasifikasikan masyarakat menjadi masyarakat statis dan masyarakat dinamis. Masyarakat statis adalah masyarakat yang mengalami perubahan yang berjalan dengan lambat. Masyarakat dinamis adalah masyarakat yang mengalami perubahan secara cepat. Jadi setiap masyarakat pada suatu masa dapat dianggap sebagai masyarakat statis, sedangkan pada masyarakat yang lainnya dianggap sebagai masyarakat dinamis. Joseph S. Roucek dan Ronald L. Warren berpendapat bahwa Perubahan sosial juga dipermudah dengan adanya kontrak dengan kebudayaan lain. Melalui hubungan seperti inilah maka difusi yang merupakan sumber kebanyakan dari pada perubahan kebudayaan itu berlangsung. Banyak masyarakat yang telah mengalami perubahan sosial yang pesat dan telah menjadi tempat pertemuan orang-orang dari berbagai kebudayaan. Sebaliknya masyarakat yang terpencil cenderung menunjukan perubahan yang teratas.

Kehidupan sosial yang dirasakan masyarakat Dolly yang menggantungkan hidupnya pada lokalisasi pasca penutupan salah satunya yaitu terjadi kesenjangan sosial antara masyarakat yang menggantungkan kehidupan sosialnya dengan Pemerintah Kota Surabaya, ketika penutupan terjadi masyarakat lokalisasi kaget karena tidak ada persiapan maupun pemberitahuan secara intens dari pihak pemerintah Kota Surabaya itu sendiri. Selain itu, masyarakat juga menganggap pemerintah Kota Surabaya kurang perduli dengan masalah ini, lantaran tindak lanjut dari pemerintah pasca penutupan dinilai kurang maksimal dan jauh dari apa yang diharapka oleh masyarakat. Pesangon yang tidak seberapa dan juga tidak merata maupun juga pelatihan (UKM) Usaha Kecil Menengah yang terkesan hanya sebagai formalitas topeng tanggung jawab pemerintah kepada warganya, karena hanya dilaksanakan dalam dua hari pelatihan. 
Sedangkan kehidupan ekonomi masyarakat Dolly yang menggantungkan hidupnya di lokalisasi pasca penutupan diantaranya yaitu, masyarakat kehilangan pekerjaan sehari-hariyang selama ini mereka lakukan selama lokalisasi masih buka. Mulai dari pedagang makanan keliling, pedagang makanan yang menetap, tukang parkir, toko klontong, laundry, bahkan hingga Pekerja Seks maupun mucikari itu sendiri. Dan masyarakat sekitar lokalisasi juga yang ikut merasakan penurunan pendapatan yang drastis dari pendapatan biasanya ketika lokalisasi masih aktif beroperasi. Karena penutupan lokalisasi Dolly ini merupakan penutupan yang dilakukan secara serempak dan aktif maka sesuai dengan wawancara saya kepada beberapa pedagang asongan di wilayah eks lokalisasi ini, mereka menegaskan bahwa penurunan omset mereka menurun hinga 1/2 persen dari omset biasanya ketika lokalisasi aktif beroperasi.

Dari permasalahan tersebut, masyarakat hanya bisa mengharapkan tanggung jawab dan perhatian dari pemerintah. Mereka mengharapkan supaya pesangon atau kompensasi dari pemerintah segera cair, dan mereka juga mengharapkan supaya pemberian keterampilan untuk usaha bisa berjalan dengan lancar. Bagi masyarakat yang tidak menggantungkan kehidupannya di lokalisasi Dolly, mereka merasa senang bahkan mendukung kebijakan pemerintah Kota Surabaya mengenai penutupan lokalisasi. Lantaran selama kegiatan di lokalisasi masih beroperasi mereka merasa tidak nyaman karena setiap hari disuguhi dengan bisingnya musik-musik dan nyanyian, belum lagi rami dan macetnya jalan di daerah lokalisasi tersebut, mengingat keberadaan lokalisasi Dolly ini dekat dengan pusat Kota. Masyarakat menjadi malu karena lingkungan mereka ini dikenal sebagai lingkungan kotor. Sehingga dirasa masyarakat, penutupan lokalisasi malah membawa dampak positif. Diantara dampak sosial yang dirasakan masyarakat yaitu, masyarakat menjadi merasa nyaman dan tentram dari keramaian, kerisauan dan kebisingan musik-musik dan nyanyian yang keras. Prostitusi memang dapat dikatakan tidak sesuai dengan norma-norma yang ada di Indonesia, karena eksistensi dari prostitusi sendiri dianggap sebagai sampah masyarakat dan juga sumber berbagai masalah-masalah, baik masalah bagi masyarakat pada umumnya maupun bagi masyarakat sekitar yang ada di dekat lokalisasi. Permasalahan itu meliputi penyebaran penyakit menular (PMP) terutama AIDS, kenakalan remaja akibat pergaulan bebas, Maka adanya kebijakan pemerintah Kota Surabaya mengenai penutupan lokalisasi itu merupakan langkah dan tujuan utama untuk mengatasi berbagai masalah yang berawal dari lokalisasi. 
PSK merupakan hal yang lumrah terjadi dimanapun di Kota besar oleh sebab itu, tentunya sangat diperlukan suatu pengelompokkan tertentu bagi kaum-kaum pekerja seks agar tidak malah menimbulkan masalah yang tidak terkontrol di dalam masyarakat luas, yang dimaksud dengan pengelompokan disini adalah fungsi dari adanya lokalisasi itu sendiri agar tidak menimbulkan masalah yang lebih besar seperti misalnya berpindahnya para pelaku seks komersil dari wilayah lokalisasi yang di gusur ke wilayah lingkungan masyarakat dan kemudian membuka praktek-praktek prostitusi terselubung hingga dapat menyebabkan berbagai masalah yang tideak bisa dianggap remeh. penutupan lokalisasi seharusnya memberikan dampak kesejahteraan umum bagi eks PSK maupun masyarakat sekitar, jangan sampai keputusan yang diambil malah memarginalkan pihak tertentu yang juga memiliki hak yang sama dalam bernegara. Hal tersebut yang membedakan penelitian ini dengan penelitian yang lainnya maupun penelitian terdahulu yang mengambil objek tentang PSK dan lokalisasi ataupun Dolly pada khususnya, karena di dalam penelitian ini saya tidak hanya melihat tentang kehidupan sosial ekonomi masyarakat Dolly itu sendiri, tetapi juga ada pertanyaan dalam benak saya tentang mengapa masyarakat maupun pekerja di eks lokalisasi tersebut begitu menggantungkan hidupnya pada lokalisasi tersebut hingga memakan korban jiwa dan rela mengorbankan segalanya demi mendapatkan lahan mata pencaharian pada lokalisasi tersebut.

\section{Metode Penelitian.}

Metode yang digunakan dalam penelitian ini menggunakan pendekatan penelitian kualitatif. Pengumpulan informasi dilakukan dengan menggunakan dua metode wawancara mendalam (langsung) dan juga wawancara secara On Line serta observasi di Lingkungan Dolly, Pengambilan data secara On Line ini dilakukan karena kondisi karena adanya pelarangan dan pembatasan untuk berinteraksi dengan warga karena Covid-19. Wawancara dilakukan dengan melibatkan 10 Informan yang berasal dari unsur Kepala Kelurahan, Ketua RT, Makelar, Sopir Taxi, Ibu Rumah Tangga, Exs mucikari, jasa penyewa baju PSK, Pemilik Toko sembako, Pemilik KUB kerajinan sandal. Ke sepuluh informan tersebut diambil dengan cara purposive dengan mempertimbangkan semua unsur yang mengetahui tentang Doly. 


\section{Temuan dan Pembahasan.}

Interaksionalisme simbolik memberikan banyak penekanan pada individu yang aktif dan kreatif ketimbang pendekatan-pendekatan teoritis lainnya. Interaksionalisme simbolik menganggap bahwa segala sesuatu tersebut adalah virtual. Semua interaksi antar individu manusia melibatkan suatu pertukaran simbol. Esensi dari interaksi simbolik yakni adalah suatu aktivitas yang merupakan ciri khas manusia yakni komunikasi atau pertukaran simbol yang diberi makna (Mulyana,2003:59) Interaksionalisme simbolik sebagai suatu perspektif melalui empat ide dasar.

Kaum perempuan sebagai penjaja seks komersial selalu menjadi objek dan tudingan sumber permasalahan dalam upaya mengurangi praktek prostitusi (Departemen Kesehatan Republik Indonesia, 2003). Prostitusi juga muncul karena ada definisi sosial di masyarakat bahwa wanita sebagai objek seks (Agus, 2002). Pekerja seks komersial pada umumnya adalah seorang wanita. Wanita adalah mahluk bio-psiko-sosial-kultural dan spiritual yang utuh dan unik, mempunyai kebutuhan dasar yang bermacam - macam sesuai dengan tingkat perkembangannya. Wanita/ibu adalah penerus generasi keluarga dan bangsa sehingga keberadaan wanita sehat jasmani dan rohani serta sosial sangat diperlukan. Wanita/ibu adalah pendidik pertama dan utama dalam keluarga (Ikatan Bidan Indonesia, 2006).

Pekerja Seks Komersial PSK merupakan profesi yang sangat tua usianya, setua umur kehidupan manusia itu sendiri. PSK selalu ada sejak zaman purba sampai sekarang. Pada masa lalu PSK selalu dihubungkan dengan penyembahan dewa-dewa dan upacaraupacara keagamaan tertentu. Ada praktek-praktek keagamaan yang menjurus pada perbuatan dosa dan tingkah laku cabul yangtidak ada bedanya dengan kegiatan PSK. Pada zaman kerajaan Mesir Kuno, Phunisia, Assiria, Chalddea, Ganaan dan di Persia, penghormatan terhadap dewa dewaIsis, Moloch, Baal, Astrate, Mylitta, Bacchus dan dewa-dewa lain disertai orgie-orgie. Orgie (orgia) adalah pesta kurban untuk para dewa, khususnya pada dewa Bacchus yang terdiri atas upacara kebaktian penuh rahasia dan bersifat sangat misterius disertai pesta-pesta makan dengan rakus dan mabuk secara berlebihan.Orang-orang tersebut juga menggunakan obat-obat pembangkit dan perangsang nafsu seks untuk melampiaskan hasrat berhubungan seksual secara terbuka. Sehubungan dengan itu, kuil-kuil pada umumnya dijadikan pusat perbuatan asusila (Kartini, 2005: 209). Di Indonesia PSK telah terjadi sejak zaman Kerajaan Majapahit. 
Berdasarkan teori Interaksionalisme simbolik yang dikemukakan oleh mead, ada tiga prinsip utama yaitu : Pertama, seseorang bertindak dan berperilaku sesuai dengan makna yang di interpretasikan dari perilaku atau tindakannya. Contoh, ketika peneliti melakukan penelitian di lokalisasi Dolly, peneliti menempatkan diri sebagai seorang mahasiswa yang sedang melakukan penelitian namun dengan interpretasi diri seperti itu peneliti menemukan banyak hambatan dan kesulitan dalam mewawancarai informaninforman tertentu seperti PSK, Mucikari/Germo untuk mendapatkan data yang akurat. Oleh sebab itu peneliti memutuskan untuk menginterpretasikan diri sebagai seorang remaja yang penasaran dengan gemerlap dunia malam Dolly yang pernah terjadi di Kota Surabaya. Kedua, makna sosial merupakan hasil konstruksi sosial. Ketika peneliti berpikir sebagai seorang peneliti maka ia akan berperilaku sebagai seorang peneliti. Hal ini tentunya membuat data yang di ambil terkesan data yang "kaku" oleh sebab itu peneliti selalu berpikir memposisikan diri sebagai seorang remaja yang penasaran dengan dunia malam Dolly, sehingga interaksi yang dilakukan antara peneliti dan informan adalah interaksi yang alami apa adanya dengan demikian dapat memudahkan peneliti untuk mendapatkan data melalui keakraban yang terjalin antara peneliti dan informan. Ketiga, penciptaan makna sosial dan pemahaman makna sosial merupakan proses interaktif yang terus berlangsung. Apa yang sudah terkonstruksi melalui pikiran dan tindakan peneliti menjadi hal yang terus berlangsung dalam proses interaksi guna mendapatkan data dari informan.

Lokasi Dolly merupakan lokasi lokalisasi terbesar se Asia Tenggara belum ada catatan pembanding resmi dengan kompleks lokalisasi di negeri lain, misalnya; kawasan Phatpong di Bangkok, Thailand dan Geylang di Singapura. Lokalisasi ini hampir menyelimuti seluruh jalan di kawasan itu. Bahkan, Dolly lebih dikenal ketimbang Kota Surabaya sendiri. Para bule yang sering mangkal di Bali pun kerap menyeberang ke Surabaya hanya untuk 'menjajal' wanita-wanita malam yang dijajakan di Dolly. Bicara soal Dolly, tak banyak yang tahu tentang bagaimana sejarah lokalisasi ini berdiri hingga bisa besar dan terkenal seperti sekarang. Sejarah mencatat, kawasan Dolly rupanya dahulu adalah tempat pemakaman warga Tionghoa pada zaman penjajahan Belanda. Namun pemakaman ini disulap oleh seorang Noni Belanda bernama Dolly sebagai tempat prostitusi khusus bagi para tentara negeri kincir angin itu. Bahkan keturunan tante Dolly juga disebut-sebut masih ada hingga kini malah tidak meneruskan bisnis esek-esek ini. Sebagai pencetus komplek lokalisasi di Jalan Jarak, Kelurahan Putat Jaya, Kecamatan 
Sawahan, Kota Surabaya ini maka perempuan dengan sebutan tante Dolly itu kemudian dikenal sebagai tokoh melegenda tentang asal muasal terbentuknya gang lokalisasi prostitusi tersebut. Dalam beberapa kisah tutur informan yang di temui oleh peneliti, awal pendiriannya, tante Dolly hanya menyediakan beberapa gadis untuk menjadi pekerja seks komersial. Melayani dan memuaskan syahwat para tentara Belanda. Seiring berjalannya waktu, ternyata pelayanan para gadis asuhan tante Dolly tersebut mampu menarik perhatian para tentara untuk datang kembali. Dalam perkembangannya, gang Dolly semakin dikenal masyarakat luas. Tidak hanya prajurit Belanda saja yang berkunjung, namun warga pribumi dan saudagar yang berdagang di Surabaya juga ikut menikmati layanan PSK. Sehingga kondisi tersebut berpengaruh kepada kuantitas pengunjung dan jumlah PSK. Dolly juga menjelma menjadi kekuatan dan sandaran hidup bagi penduduk di sana.

Dolly yang dulu setiap harinya disibukan dengan aktifitas prostitusi manusia, Pekerja Seks Komersial (PSK) yang setiap harinya dipamerkan untuk dijajakan kepada pemuas nafsu lelaki hidung belang kini telah berubah menjadi satu perkampungan yang sunyi senyap layaknya perkampungan pada umunya, sudah tidak ada lagi wanita PSK yang dipamerkan didalam setiap wisma, tidak ada lagi musik kencang yang menggangu aktifitas warga dan anak anak khususnya.

Semenjak ditutup oleh Pemerintah Kota Surabaya Dolly kini mulai berubah menjadi lebih baik lagi. Awal mula tujuan utama penutupan lokalisasi Dolly dan yang tentunya menuai banyak tanggapan pro dan kontra dari berbagai pihak terkait, mulai dari pihak pemerintahan maupun pihak masyarakat yang terkena dampak penutupannya yakni masyarakat eks lokalisasi Dolly sendiri yang tentunya semua itu harus berjalan beriringan antara pihak pemerintahan sebagai sosok elit dan masyarakat agar segala bentuk program rencana yang ada bisa berjalan dengan baik, tanpa merugikan salah satu pihak, dan yang terpenting bersifat adil agar tidak ada kesalapahaman antara elit pemerintah maupun masyarakat.

Proses penutupan lokalisasi Dolly nyata nya sampai saat ini masih belum bisa dikatakan murni tutup dan berhenti, faktanya masih terjadi kesimpang-siuran yang ditemukan oleh peneliti dari beberapa informan, baik itu dari pihak pemerintah maupun masyarakat. Sebagian masyarakat masih merasa tidak rela dan tidak ikhlas ladang rupiahnya selama berupuluh puluh tahun ditutup begitu saja, tempat mencari nafkah untuk anak dan keluarga dirumah yang selama ini mereka banggakan kini harus ditutup oleh 
pemerintah. Selain itu bentuk perubahan yang terjadi sebelum dan setelah ditutupnya eks lokalisasi Dolly adalah perubahan daripekerjaan atau profesi masyarakat. Ada yang memang profesi nya bukan di eks lokalisasi Dolly atau bukan masyarakat terdampak, ada yang beralih profesi menjadi lebih baik lagi daripada sebelum lokalisasi Dolly ditutup dan ada yang berprofesi masih tetap sebelum dan setelahnya ditutup. Dari temuan dilapangan, sebagian masyarakat merasakan perubahan semenjak ditutupnya eks lokalisasi Dolly, ada perubahan yang mengarah ke kebaikan yang akhirnya mereka bersyukur atas ditutupnya lokalisasi Dolly, ada yang perubahannya justru bisa dikatakan menurun atau buruk dan ada pula tidak merasakan perubahan sama sekali. Seperti yang dikatakan oleh beberapa informan yang berhasil peneliti temukan di lapangan.

Seperti penuturan dari seorang Bapak yang tidak mau disebutkan nama aslinya, dulu pekerjaannya ialah sebagai supir taksi sekarang membuka warung kopi di eks gang Dolly. Beliau mempunyai nama samaran yang cukup tenar di eks lokalisasi Dolly, yang akrab dipanggil dengan nama Roni (44).

Terdapat lebih dari 800 wisma esek-esek, kafe dangdut dan panti pijat plus yang berjejer rapi. Setidaknya setiap malam sekitar 9.000 lebih penjajak cinta, pelacur di bawah umur, germo, ahli pijat siap menawarkan layanan kenikmatan kepada para pengunjung. Tidak hanya itu, Dolly juga menjadi tumpuan hidup bagi ribuan pedagang kaki lima, tukang parkir, dan calo prostitusi. Semua saling berkait menjalin sebuah simbiosis mutualisme. Kisah lain tentang Dolly juga pernah ditulis Tjahjo Purnomo dan Ashadi Siregar dalam buku berjudul "Dolly: Membedah Dunia Pelacuran Surabaya, Kasus Kompleks Pelacuran Dolly" yang diterbitkan Grafiti Pers, April 1982. Dalam buku itu disebutkan dulu kawasan Dolly merupakan makam Tionghoa, meliputi wilayah Girilaya, berbatasan dengan makam Islam di Putat Gede. Baru sekitar tahun 1966 daerah itu diserbu pendatang dengan menghancurkan bangunan-bangunan makam. Makam China itu tertutup bagi jenazah baru, dan kerangka lama harus dipindah oleh ahli warisnya. Ini mengundang orang mendapatkan tanah bekas makam itu, baik dengan membongkar bangunan makam, menggali kerangka jenazah, atau cukup meratakan saja. Setahun kemudian, 1967, muncul seorang pelacur wanita bernama Dolly Khavit di kawasan makam Tionghua tersebut. Dia kemudian menikah dengan pelaut Belanda, pendiri rumah pelacuran pertama di jalan yang sekarang bernama Kupang Gunung Timur I. Wisma miliknya antara lain bernama T, Sul, NM, dan MR. Tiga di antara empat wisma itu disewakan pada orang lain. Demikian asal muasal nama Dolly. Dolly semakin 
berkembang pada era tahun 1968 dan 1969. Wisma-wisma yang didirikan di sana semakin banyak. Adapun persebarannya dimulai dari sisi jalan sebelah barat, lalu meluas ke timur hingga mencapai sebagian Jalan Jarak. Sebagai komparasi antara Dolly dulu dan sekarang maka haruslah kita melihat dari segi perubahan sosial yang sudah terjadi di lokalisasi Dolly itu sendiri.

Berdasarkan data dari informan, peneliti menemukan fakta bahwa sebenarnya ada banyak faktor pendorong seseorang ingin terjun kedalam dunia prostitusi tetapi juga sebaliknya sangat banyak sekali faktor pendorong yang membuat seseorang tidak ingin dekat dengan dunia malam seperti itu. Hal tersebut dibuktikan dengan banyaknya informan yang justru bersyukur dengan perubahan sosial yang terjadi pasca penutupan lokalisasi Dolly itu sendiri, bahkan dari kalangan "pelaku utama" di lokalisasi Dolly tetapi juga sebaliknya ada juga yang merasa kehilangan sumber mata pencaharian, namun peneliti menilai hal tersebut adalah hal yang normal ketika terjadi perubahan sosial yang dilakukan secara besar-besaran seperti penutupan lokalisasi Dolly itu sendiri. Perubahan sosial bisa terjadi karena adanya perubahan pola hidup di masyarakat, serta menyempurnakan kebutuhan serta kehidupan mereka. Hal inilah yang menjadi dasar munculnya teori-teori tentang perubahan sosial, salah satunya ialah teori tersebut ialah teori evolusi. Teori evolusi menatakan bahwa manusia mengalami perubahan sosial dari waktu ke waktu, dari peradaban yang sederhana menuju peradaban yang lebih kompleks seperti zaman sekarang ini. Hal tersebut di picu oleh kebutuhan serta keinginan manusia untuk melakukan perubahan sosial tersebut. Menurut Alex Inkeles perubahan ini disebut dengan teori evolusi, dimana ada tahapan-tahapan yang harus dilalui oleh manusia dalam melakukan perubahan sosial. Namun ia juga menyebutkan bahwa terdapat perubahan sosial yang tidak membutuhkan tahapan dan berlangsung secara cepat maupun konstan.

Menurut Alex Inkeles dalam bukunya What is Sociology (1965) perubahan sosial dapat di golongkan ke dalam beberapa kategori sebagai berikut:

\section{a. Unilinear Theories Of Education}

Mengatakan bahwa masyarakat (termasuk kebudayaannya) mengalami perkembangan dengan tahap-tahap tertentu. Bermula dari bentuk yang sederhana kemudian menuju yang kompleks sampai pada tahap yang sempurna.

\section{b. Universal Theory Of Evolution}

Menyatakan bahwa perkembangan masyarakat itu tidak perlu mengikuti tahaptahap tertentu yang tetap, karena perubahan sosial itu telah mengikuti garis evolusi 
tertentu. Prinsip teori ini diuraikan oleh Herbert Spencer yang menyebutkan bahwa masyarakat merupakan hasil perkembangan dari kelompok homogen ke kelompok yang heterogen, baik sistem maupun strukturnya.

\section{c. Multilined Theories Of Evolution}

Merupakan penggabungan dari kedua teori diatas. Teori ini lebih menekankan perlunya penelitian empiris terhadap perubahan-perubahan sosial yang terjadi dalam masyarakat secara ilmiah, seperti penelitian terhadap sistem mata pencaharian, sistem kemasyarakatan, sistem kekerabatan, dan sebagainya.

Dalam hal ini kita bisa melihat bahwa perubahan sosial yang terjadi di Dolly merupakan perubahan yang bersifat multilined theories of evolution, dimana dalam mengkajinya diperlukan penelitian yang empiris, namun secara garis besar di zaman seperti sekarang ini, perubahan sosial merupakan perubahan yang terjadi di dalam masyarakat karena terjadinya pertukaran ideologi maupun pertukaran teknologi, dengan demikian perubahan sosial yang terjadi di wilayah lokalisasi Dolly bisa dikatakan sebagai perubahan sosial yang terjadi karena stigma masyarakat luar terhadap Kota Surabaya maupun keinginan dari sebagian besar warga Kota Surabaya untuk hidup bersama agar dapat sama-sama menuju kepada keadaan sosial yang lebih baik, bukan Cuma baik secara materiil namun baik juga secara moriil.

Hal tersebut dibuktikan dengan banyaknya UKM (Usaha Kecil Menengah) yang dibangun diatas lahan eks lokalisasi Dolly dengan bantuan pemerintah Kota Surabaya dalam satu tujuan yaitu mengentaskan Dolly dari stigma buruk yang ada di masyarakat, meskipun kita tau bahwa fakta lokalisasi terselubung akan tetap ada karena seperti yang sudah dijelaskan diawal tulisan ini, bahwa lokalisasi sendiri merupakan "tempat sampah" dimana hal-hal "kotor" ditemukan. Merubah kebiasaan dan keaadan sosial masyarakat yang sudah mendarah daging memanglah butuh proses yang panjang dan nantinya di kemudian hari tentunya akan ada perubahan-perubahan besar yang terjadi yang memaksa manusia untuk selalu siap dalam menghadapi perubahan sosial tersebut. 


\section{Kesimpulan.}

Beberepa kesimpulan dapat dikemukakan sebagai berikut:

a. Bentuk perubahan yang ada pada sektor mata pencaharian atau profesi. Dari yang awalnya dulu bekerja sebagai supir taksi yang ngetem di eks lokalisasi Dolly, sekarang beralih membuka usaha warung kopi, seorang ibu yang dulunya hanya sebagai ibu rumah tangga kini beralih untuk mengikuti usaha kerajinan yang diberikan oleh pemerintah kepada warga masyarakat eks lokalisasi Dolly, dan ada pula yang sejak dulu sebelum ditutup sampai sudah ditutup mempunyai profesi atau mata pencaharian yang masih tetap saja sama.

b. Tipologi masyarakat eks lokalisasi Dolly pada masa perubahan bervariasi, yaitu antara lain:

1. Masyarakat eks lokalisasi yang hanya dari dulu bertempat tinggal saja atau memiliki hunian di eks lokalisasi Dolly dan tidak termasuk dalam masyarakat terdampak penutupan lokalisasi.

2. Masyarakat yang mengikuti arus perubahan dari penutupan eks lokalisasi Dolly yang dulunya mencari nafkah di gang Dolly kini mulai beralih mencari pekerjaan yang lebih baik dan lebih positif lagi.

Masyarakat yang dulu bekerja di eks lokalisasi Dolly sebagai makelar dan mucikari bahkan Pekerja Seks Komersial (PSK) kini masih tetap mencari nafkah di eks lokalisasi Dolly tapi bisa dikatakan lebih tertutup atau tersembunyi.

\section{Daftar Pustaka.}

Agustianingsih, Diana. 2014. Pengaruh sikap masyarakat terhadap sosial Facebook serta implikasinya terhadap ketahanan sosial budaya. Jurnal Ketahan Nasional, Vol. 20 (1) : 14-16.

Cornelius Prastya R. K dan Adi Darma. 2011. Dolly: Kisah Pilu yang Terlewatkan. Yogyakarta : Pustaka Pena.

Kusumastuty, Weny. 2009. Dinamika kognisi sosial ekonomi pada pelacur terhadap penyakit menularseksual. Indigenous, Jurnal Ilmiah Berkala Psikologi. Vol, 11 (2) : 19-28 
Patnani, Miwa. 2009. Prostitusi antara pilihan dan keterpaksaan.Indigenous, Kognisi, Majalah Ilmiah Psikologi, Vol, 3 (2) : 57-60

Rachmadika, Dearwinda. 2017. Pemberdayaan eks pekerja seks komersil (PSK) Dolly melalui pelatihan ketrampilan pembuatan sepatu di kub Mampu Jaya Kelurahan Putat Kecamatan Sawahan Kota Surabaya. Jurnal Mahasiswa Unesa, Vol, 3 (1) : 5-8

Rusyidi, Binahayati. 2018. Penanganan Pekerja Seks Komersial di Indonesia. Jurnal Unpad, Prosiding Pengabdian dan Penelitian Kepada Masyarakat,Vol. 5 (3) : 308-309.

Saputra, Akmal. 2015. Potret Lokalisasi Gang Dolly dalam Perspektif Patologi Sosial. Jurnal Community, Vol.1 (1) : 63-65.

Sedyaningsih, Endang R. 2010. Pererempuan-perempuan Kramat Tunggak. Jakarta : Kepustakaan Populer Gramedia.

Syam, Nur. 2011. Agama Pelacur. Jakarta : LKis.

Sztompka, Piotr. 2017. Sosiologi Perubahan Sosial. Di terjemahkan oleh Alimandan. Jakarta : Prenada Media Group.

Teguh, Imam. 2016. Perubahan spsial masyarakat eks lokalisasi dolly. 